Jurnal Akuntansi dan Keuangan (JAK)

Volume 6, No. 2 Oktober Tahun 2021

Page: 80 - 96

http://ojs.uho.ac.id/index.php/jak-uho/issue/archive

e-ISSN: 2088-4656

\title{
PENGARUH SIMPANAN DAN PINJAMAN ANGGOTA \\ TERHADAP SISA HASIL USAHA (STUDI PADA KOPERASI SERBA USAHA \\ BINA SEJAHTERA, DESA LEMOAMBO, KABUPATEN MUNA BARAT)
}

\author{
Andi Basru Wawo ${ }^{1}$, Sitti Nurnaluri ${ }^{2}$, Fathu Rahman ${ }^{3}$ \\ Jurusan Akuntansi Fakultas Ekonomi dan Bisnis Universitas Halu Oleo Kendari \\ Sulawesi Tenggara
}

\begin{abstract}
ABSTRAK
Penelitian ini bertujuan untuk menguji dan mengetahui pengaruh Simpanan dan Pinjaman Anggota terhadap Sisa Hasil Usaha Koperasi pada Koperasi Serba Usaha Bina Sejahtera. Metode pengumpulan data dalam penelitian menggunakan dokumentasi. Data yang digunakan adalah data sekunder berupa catatan simpanan anggota, pinjaman anggota, dan Sisa Hasil Usaha. Metode penelitian yang digunakan adalah metode analisis deskriptif dan analisis regresi linear berganda dengan bantuan aplikasi software IBM SPSS Statistic Versi 25. Hasil penelitian ini menunjukkan bahwa (1) simpanan anggota secara parsial berpengaruh signifikan dan positif terhadap Sisa Hasil Usaha Koperasi, (2) pinjaman anggota secara parsial berpengaruh signifikan dan positif terhadap Sisa Hasil Usaha, (3) serta simpanan dan pinjaman anggota secara simultan berpengaruh signifikan terhadap Sisa Hasil Usaha Koperasi. Kesimpulan dalam penelitian ini yaitu semakin meningkat jumlah simpanan anggota dan pinjaman anggota akan meningkatkan jumlah Sisa Hasil Usaha Koperasi.
\end{abstract}

\section{Kata Kunci : Simpanan Anggota, Pinjaman Anggota, Sisa Hasil Usaha}

\begin{abstract}
This study aims to examine and determine the effect of Member Saving and Loan on the Remaining Profits of Cooperatives at the Multipurpose Cooperative Bina Sejahtera. The method of data collection in this study uses documentation. The data used is secondary data in the form of records of member saving, member loan, and remaining operation balance. The research method used is descriptive analysis method and multiple linear regression analysis with the help of the IBM SPSS Statistic Version 25 software application. The balance of this study indicate that (1) member saving partially have a significant and positive effect on the remaining operation income of cooperatives, (2) member loan partially have a significant and positive effect on remaining operation balance, (3) and member saving and loan simultaneously have a significant effect on remaining operation balance of cooperatives. The conclusion in this study is that the increasing number of member saving and member loan will increase the amount of the remaining operation balance of the cooperative.
\end{abstract}

Keywords: Member Saving, Member Loan, Remaining Operation Balance 
Jurnal Akuntansi dan Keuangan (JAK)

Volume 6, No. 2 Oktober Tahun 2021

Page: 80 - 96

http://ojs.uho.ac.id/index.php/jak-uho/issue/archive

e-ISSN: 2088-4656

\section{PENDAHULUAN}

Dalam UU No. 25 Tahun 1992 menyatakan bahwa koperasi adalah badan usaha yang beranggotakan orang seorang atau badan hukum koperasi dengan melandaskan kegiatannnya berdasarkan prinsip koperasi sekaligus sebagai gerakan ekonomi rakyat yang berdasarkan atas asas kekeluargaan. Koperasi dibentuk dan dimiliki oleh anggotanya dengan menjalankan kegiatan ekonomi dan kegiatan sosial, serta pada dasarnya dengan tujuan mensejahterakan anggotanya itu sendiri.

Koperasi dibentuk sebagai lembaga keuangan bukan bank yang dibentuk untuk mengelola dana yang dihimpun oleh anggota untuk membiayai kebutuhan koperasi dan keanggotaannya. Sekalipun mencari keuntungan bukan tujuan utama dari usaha koperasi, tetapi usaha yang dikelola oleh koperasi harus memperoleh Sisa Hasil Usaha (SHU) yang layak sehingga koperasi dapat mempertahankan kelangsungan hidupnya dan meningkatkan kemampuan usahanya (Satar dan Wulan Sari, 2019:80).

Koperasi Serba Usaha (KSU) Bina Sejahtera merupakan koperasi yang berkedudukan di Desa Lemoambo, Kecamatan Kusambi, Kabupaten Muna Barat, Provinsi Sulawesi Tenggara. KSU Bina Sejahtera merupakan koperasi yang bergerak dalam bidang usaha simpan pinjam dan pelayanan jasa dekorasi pengantin. Tetapi yang menjadi kegiatan utama dalam KSU Bina Sejahtera ini adalah usaha simpan pinjamnya.

Koperasi Serba Usaha Bina Sejahtera menghimpun dana dari para anggotanya berupa simpanan uang yang terdiri dari simpanan pokok, simpanan wajib, dan simpanan sukarela yang kemudian akan menjadi modal koperasi. Dan menyalurkan kembali kepada para anggotanya melalui proses pinjaman kredit. Keberhasilan koperasi dapat dilihat dari SHU yang diperoleh, yakni semakin tinggi SHU yang diperoleh setiap tahunnya maka menunjukkan kinerja koperasi dan koperasi dapat bertahan lebih lama dalam menjalankan usahanya. Mengingat pentingnya SHU bagi koperasi maka manajemen koperasi harus menjalankan fungsi manajemen koperasi secara baik yang meliputi perencanaan, pengorganisasian, pelaksanaan kerja sampai tahap evaluasi sesuai dengan aturan yang ada di KSU Bina Sejahtera.

Berdasarkan hasil survey pendahuluan, serta data yang diperoleh selama tiga tahun terakhir yaitu tahun 2017 - 2019 simpanan anggota, pinjaman anggota (piutang anggota), maupun Sisa Hasil Usaha (SHU) pada KSU Bina Sejahtera dapat dilihat pada tabel berikut :

Tabel. 1.1.

Jumlah Simpanan Anggota, Pinjaman Anggota, Sisa Hasil Usaha (SHU)

\begin{tabular}{|c|c|c|c|}
\hline Tahun & $\begin{array}{c}\text { Jumlah Simpanan } \\
\text { Anggota }\end{array}$ & $\begin{array}{c}\text { Jumlah Pinjaman } \\
\text { Anggota }\end{array}$ & Sisa Hasil Usaha (SHU) \\
\hline 2017 & Rp. $275.664 .000,00$ & Rp. 255.264.000,00 & Rp. 35.285.000,00 \\
\hline 2018 & Rp. 319.464.000,00 & Rp. 249.150.000,00 & Rp. 41.360.000,00 \\
\hline 2019 & Rp. 366.270.000,00 & Rp. 366.314.000,00 & Rp. 50.040.000,00 \\
\hline
\end{tabular}

Sumber : Data sekunder catatan keuangan KSU Bina Sejahtera (2021) 
Jurnal Akuntansi dan Keuangan (JAK)

Volume 6, No. 2 Oktober Tahun 2021

Page: 80 - 96

http://ojs.uho.ac.id/index.php/jak-uho/issue/archive

e-ISSN: 2088-4656

Perolehan simpanan anggota, pinjaman anggota, dan Sisa Hasil Usaha pada Koperasi Serba Usaha Bina Sejahtera selama periode tahun 2017 - 2019 mengalami fluktuasi kenaikan. Kenaikan jumlah Sisa Hasil Usaha diiringi kenaikan jumlah simpanan maupun jumlah pinjaman anggota. keberadaan partisipasi anggota dalam penghimpunan modal melalui simpanan serta partisipasi anggota dalam memanfaatkan dana tersebut dalam bentuk pinjaman atau pembiayaan erat kaitannya dengan upaya koperasi untuk meningkatkan SHU nya dari tahun ketahun. Sehingga dari uraian tersebut peneliti ingin melakukan penelitian untuk melihat bagaimana "Pengaruh Simpanan dan Pinjaman Anggota terhadap Sisa Hasil Usaha Koperasi (Studi pada Koperasi Serba Usaha Bina Sejahtera, Desa Lemoambo, Kabupaten Muna Barat)".

\section{II.LANDASAN TEORI}

\section{Akuntansi Koperasi}

Akuntansi koperasi adalah suatu seni pencatatan, pengklasifikasian, pelaporan dan penafsiran laporan keuangan koperasi dalam satu periode tertentu. Di mana periode tersebut mungkin bulanan, tiga bulanan, enam bulanan atau tahunan pada koperasi. (Satar dan Wulan Sari, 2019)

\section{Konsep Koperasi}

Konsep koperasi menjadi dua yaitu konsep koperasi barat dan konsep koperasi sosialis. Hal ini dilatar belakangi oleh pemikiran bahwa pada dasarnya, perkembangan konsep-konsep yang ada berasal dari negara-negara barat dan berpaham sosialis, sedangkan konsep yang berkembang di negara dunia ketiga merupakan perpaduan dari kedua konsep tersebut. (Sattar, 2017)

\section{Pengertian Koperasi}

Secara etimologi istilah "co-operation" yang artinya kerja sama. Di mana "Koperasi" berasal dari bahasa Latin yakni "coopere", yang dalam bahasa inggris disebut dengan "cooperation". Co mengandung arti "bersama" dan operation artinya "usaha", penggabungan dua kata ini akan menghasilkan sebuah kata yang mempunyai arti yaitu sebuah usaha bersama. (Shomadani dan Hasyim, 2018)

\section{Tujuan, Fungsi dan Peran Koperasi}

Menurut UU No. 25 Tahun 1992 pasal 3 dijelaskan bahwa Koperasi bertujuan memajukan kesejahteraan anggota pada khususnya dan masyarakat pada umumnya serta ikut membangun tatanan perekonomian nasional dalam rangka mewujudkan masyarakat yang maju, adil, dan makmur berlandaskan Pancasila dan Undang-Undang Dasar 1945. Dan fungsi serta peran koperasi yaitu :

a. membangun dan mengembangkan potensi dan kemampuan ekonomi anggota pada khususnya dan masyarakat pada umumnya untuk meningkatkan kesejahteraan ekonomi dan sosialnya;

b. berperan serta secara aktif dalam upaya mempertinggi kualitas kehidupan manusia dan masyarakat; 
Jurnal Akuntansi dan Keuangan (JAK)

Volume 6, No. 2 Oktober Tahun 2021

Page: 80 - 96

http://ojs.uho.ac.id/index.php/jak-uho/issue/archive

e-ISSN: 2088-4656

c. memperkokoh perekonomian rakyat sebagai dasar kekuatan dan ketahanan perekonomian nasional dengan Koperasi sebagai sokogurunya;

d. berusaha untuk mewujudkan dan mengembangkan perekonomian nasional yang merupakan usaha bersama berdasar atas asas kekeluargaan dan demokrasi ekonomi.

\section{Jenis Koperasi}

Berdasarkan UU No. 25 Tahun 1992 pasal 16 ini, Menteri Koperasi dan Usaha Kecil Menengah menyebutkan jenis Koperasi terbagi atas Koperasi Sektor Rill dan Koperasi Simpan Pinjam. Pembagian jenis koperasi ini disertai dengan Pedoman Akuntansinya, disisi lain pedoman ini didasarkan juga pada Standar Akuntansi Umum dan Standar Akuntansi Keuangan Entitas Tanpa Akuntabilitas Publik (SAK-ETAP) yang di keluarkan oleh IAI.

\section{Koperasi Simpan Pinjam}

Menurut Permen-KUKM No. 13 Tahun 2015 Bab 1 Bagian E poin 1 tentang Pengertian Umum menyebutkan bahwa Koperasi Simpan Pinjam adalah Koperasi yang melaksanakan kegiatan usahanya hanya usaha simpan pinjam. Dan di poin 2 disebutkan bahwa Usaha Simpan Pinjam adalah unit usaha koperasi yang bergerak di bidang usaha simpan pinjam sebagai bagian dari kegiatan dari usaha koperasi yang bersangkutan.

\section{Simpanan Anggota}

Menurut Rudianto (2010) dalam bukunya berjudul Akuntansi Koperasi menyatakan bahwa simpanan koperasi terdiri dari :

1. Simpanan Pokok

Simpanan pokok adalah sejumlah uang yang sama banyaknya dan atau sama nilainya yang wajib dibayarkan anggota koperasi pada saat masuk menjadi anggota. Simpanan pokok tidak dapat diambil kembali selama bersangkutan menjadi anggota.Simpanan pokok ini sifatnya permanen, artinya tidak dapat diambil selama yang bersangkutan masih menjadi anggota.

2. Simpanan Wajib

Simpanan wajib adalah sejumlah simpanan tertentu yang tidak harus sama yang wajib dibayar oleh anggota kepada koperasi pada saat masuk menjadi anggota. Simpanan wajib tidak dapat diambil selama yang bersangkutan masih menjadi anggota.

3. Simpanan Sukarela

Simpanan sukarela adalah jumlah tertentu yang diserahkan oleh anggota koperasi atas kehendak anggota koperasi sendiri.

4. Deposit Anggota

Deposit anggota berbentuk simpanan sukarela dari anggota yang identik dengan deposito di bank pada umumnya. Hal ini dapat terjadi dalam koperasi sebagai "Simpanan Deposito Anggota", yaitu simpanan anggota kepada koperasi yang penarikannya hanya dilakukan dalam jangka waktu tertentu menurut perjanjian antara pihak anggota yang bersangkutan dengan koperasi. 
Jurnal Akuntansi dan Keuangan (JAK)

Volume 6, No. 2 Oktober Tahun 2021

Page: 80 - 96

http://ojs.uho.ac.id/index.php/jak-uho/issue/archive

e-ISSN: 2088-4656

\section{Pinjaman Anggota}

Menurut Rudianto (2010) dalam bukunya berjudul Akuntansi Koperasi menyatakan bahwa "Piutang anggota adalah hak (tagihan) koperasi kepada anggota koperasi. Tagihan tersebut timbul karena koperasi menjual barang kepada anggotanya secara kredit".

\section{Sisa Hasil Usaha}

Menurut Rudianto (2010) mendefiniskan Sisa Hasil Usaha adalah selisih antara penghasilan yang diterima koperasi selama periode tertentu dengan pengorbanan (beban) yang dikeluarkan untuk memperoleh penghasilan itu. Jumlah SHU tahun berjalan akan terlihat dalam perhitungan hasil usaha.

\section{Anggota Koperasi}

Menurut UU No. 25 Tahun 1992 pasal 17 ayat 1 menjelaskan bahwa Anggota Koperasi adalah pemilik dan sekaligus pengguna jasa Koperasi.

Berdasarkan penjelasan teori di atas, maka hipotesis yang diajukan sebagai berikut :

$\mathrm{H}_{1}$ : Simpanan Anggota secara parsial berpengaruh signifikan terhadap Sisa Hasil Usaha Pada Koperasi Serba Usaha Bina Sejahtera.

$\mathrm{H}_{2}$ : Pinjaman Anggota secara parsial berpengaruh signifikan terhadap Sisa Hasil Usaha Pada Koperasi Serba Usaha Bina Sejahtera.

$\mathrm{H}_{3}$ : Simpanan dan Pinjaman Anggota secara simultan berpengaruh signifikan terhadap Sisa Hasil Usaha Pada Koperasi Serba Usaha Bina Sejahtera.

\section{III.METODE PENELITIAN}

\section{Lokasi dan Objek Penelitian}

Penelitian ini dilakukan pada Koperasi Serba Usaha Bina Sejahtera dengan Lokasi bertempat di RK 001 / RW 001 Desa Lemoambo, Kecamatan Kusambi, Kabupaten Muna Barat, Provinsi Sulawesi Tenggara. Adapun objek penelitian ini adalah pengaruh simpanan dan pinjaman anggota terhadap Sisa Hasil Usaha (SHU) pada Koperasi Serba Usaha Bina Sejahtera.

\section{Jenis dan Sumber Data}

Jenis data yang digunakan dalam penelitian ini adalah data kuantitatif yaitu meliputi jumlah simpanan anggota, jumlah pinjaman anggota (piutang anggota), dan Sisa Hasil Usaha (SHU) Koperasi Serba Usaha Bina Sejahtera. Dan sumber data dalam penelitian ini adalah data sekunder yaitu Data sekunder pada penelitian ini adalah yaitu berupa data dokumenter yang meliputi data jumlah simpanan, jumlah pinjaman anggota, dan Sisa Hasil Usaha Koperasi Serba Usaha Bina Sejahtera dengan rekapitulasi setiap bulan selama 3 tahun yaitu tahun 2017 hingga tahun 2019.

\section{Metode Pengumpulan Data}

Metode pengumpulan data yang digunakan dalam penelitian ini adalah :

1. Studi Pustaka atau literatur,

2. Dokumentasi, dan 
Jurnal Akuntansi dan Keuangan (JAK)

Volume 6, No. 2 Oktober Tahun 2021

Page: 80 - 96

http://ojs.uho.ac.id/index.php/jak-uho/issue/archive

e-ISSN: 2088-4656

3. Wawancara.

\section{Metode Analisis Data}

1. Statistik Deskriptif

Menurut Sugiyono (2017: 147), "analisis statistik deskriptif merupakan suatu uji yang bertujuan untuk menganalisis data melalui deskripsi data yang terkumpul tanpa membuat kesimpulan umum.

2. Uji Asumsi Klasik

Uji asusmsi klasik digunakan untuk mengetahui dan menguji hasil model regresi yang diperoleh dikatakan layak digunakan dalam penelitian. Uji asumsi klasik yang digunakan adalah sebagai berikut :

a. Uji Normalitas

Uji normalitas bertujuan untuk menguji apakah dalam model regresi, variabel dependen dan variabel independen memiliki distribusi data yang normal atau tidak. (Ghozali, 2016)

b. Uji Multikolinearitas

Uji multikolinearitas bertujuan untuk menguji apakah model regresi ditemukan adanya korelasi antar variabel bebas (independent). (Ghozali, 2016)

c. Uji Heteroskedastisitas

Uji heteroskedastisitas bertujuan untuk menguji apakah model regresi terjadi ketidaksamaan varians dari residual satu pengamatan ke pengamatan yang lain. (Ghozali, 2016)

d. Uji Autokorelasi

Uji autokorelasi bertujuan untuk menguji apakah dalam suatu model regresi ada korelasi antara penyimpangan pada periode t pada periode t-1 (sebelumnya). (Ghozali, 2016)

\section{Analisis Regresi Linear Berganda}

Menurut Sugiyono (2017) "tujuan dari analisis regresi linear berganda adalah untuk memprediksi fluktuasi veriabel dependen dengan kondisi dua atau lebih variabel". Penelitian ini menggunakan analisis linear berganda untuk mengetahui pengaruh simpanan anggota dan pinjaman anggota terhadap Sisa Hasil Usaha koperasi. Model persamaan garis regresi 2 variabel yang digunakan adalah sebagai berikut :

$$
Y=\alpha+\beta_{1} X_{1}+\beta_{2} X_{2}+
$$

Keterangan:

$$
\begin{array}{ll}
\mathrm{Y} & =\text { Sisa Hasil Usaha } \\
\alpha & =\text { Konstanta } \\
\mathrm{X}_{1} & =\text { Simpanan Anggota } \\
\mathrm{X}_{2} & =\text { Pinjaman Anggota } \\
\beta & =\text { Koefisien Regresi }
\end{array}
$$


Jurnal Akuntansi dan Keuangan (JAK)

Volume 6, No. 2 Oktober Tahun 2021

Page: 80 - 96

http://ojs.uho.ac.id/index.php/jak-uho/issue/archive

e-ISSN: 2088-4656

$\mathrm{E}=$ Error Term (Standar Error)

Uji Hipotesis

Pengujian hipotesis dilakukan melalui uji statistik $\mathrm{F}$, uji statistik $\mathrm{t}$, dan uji koefisien determinasi $\left(\mathrm{R}^{2}\right)$. Hipotesis dalam penelitian ini diuji dengan menggunakan model regresi berganda.

\section{HASIL DAN PEMBAHASAN}

\section{Deskripsi Variabel Penelitian}

Penelitian ini dilakukan di Koperasi Serba Usaha (KSU) Bina Sejahtera yang bertempat di Desa Lemoambo, Kecamatan Kusambi, Kabupaten Muna Barat, Provinsi Sulawesi Tenggara dengan tujuan untuk mengetahui signifikannya pengaruh Simpanan Anggota dan Pinjaman Anggota terhadap Sisa Hasil Usaha antara tahun 2017 s.d 2019. Berikut data jumlah simpanan anggota, jumlah pinjaman anggota, dan jumlah Sisa Hasil Usaha (SHU) KSU Bina Sejahtera antara 2017 s.d 2019 :

Data Variabel Simpanan Anggota KSU Bina Sejahtera

\begin{tabular}{|c|c|c|c|c|}
\hline \multicolumn{5}{|c|}{ DATA SIMPANAN ANGGOTA 2017} \\
\hline \multirow{2}{*}{ Bulan } & \multicolumn{3}{|c|}{ Simpanan } & \multirow{2}{*}{ Jumlah (Rp) } \\
\hline & Pokok (Rp) & Wajib (Rp) & Sukarela $(\mathrm{Rp})$ & \\
\hline Januari & 39.900 .000 & 3.190 .000 & - & 43.090 .000 \\
\hline Februari & 39.900 .000 & 3.250 .000 & - & 43.150 .000 \\
\hline Maret & 39.900 .000 & 3.300 .000 & 250.000 & 43.450 .000 \\
\hline April & 39.900 .000 & 3.300 .000 & 70.000 & 43.270 .000 \\
\hline Mei & 39.900 .000 & 3.350 .000 & 40.000 & 43.290 .000 \\
\hline Juni & 39.900 .000 & 3.400 .000 & 140.000 & 43.440 .000 \\
\hline Juli & 39.900 .000 & 3.400 .000 & 1.180 .000 & 44.480 .000 \\
\hline Agustus & 39.900 .000 & 3.350 .000 & - & 43.250 .000 \\
\hline September & 39.900 .000 & 3.300 .000 & 240.000 & 43.440 .000 \\
\hline Oktober & 39.900 .000 & 3.250 .000 & 130.000 & 43.280 .000 \\
\hline November & 39.900 .000 & 3.300 .000 & 385.000 & 43.585 .000 \\
\hline Desember & 39.900 .000 & 3.300 .000 & 20.390 .000 & 63.590 .000 \\
\hline Jumlah & 39.900 .000 & 39.690 .000 & 22.825 .000 & 2.415 .000 \\
\hline \multicolumn{5}{|c|}{ DATA SIMPANAN ANGGOTA 2018} \\
\hline \multirow[b]{2}{*}{ Bulan } & & Simpanan & & \multirow[b]{2}{*}{ Jumlah (Rp) } \\
\hline & $\begin{array}{r}\text { Pokok } \\
(\mathrm{Rp}) \\
\end{array}$ & $\begin{array}{l}\text { Wajib } \\
\text { (Rp) }\end{array}$ & $\begin{array}{r}\text { Sukarela } \\
(\mathrm{Rp})\end{array}$ & \\
\hline Januari & 41.900 .000 & 3.200 .000 & 2.501 .000 & 47.601 .000 \\
\hline Februari & 41.900 .000 & 3.200 .000 & 708.000 & 45.808 .000 \\
\hline Maret & 41.900 .000 & 3.250 .000 & 3.781 .000 & 48.931 .000 \\
\hline April & 41.900 .000 & 3.250 .000 & 50.000 & 45.200 .000 \\
\hline Mei & 41.900 .000 & 3.200 .000 & - & 45.100 .000 \\
\hline Juni & 41.900 .000 & 3.150 .000 & 500.000 & 45.550 .000 \\
\hline
\end{tabular}


Jurnal Akuntansi dan Keuangan (JAK)

Volume 6, No. 2 Oktober Tahun 2021

Page: 80 - 96

http://ojs.uho.ac.id/index.php/jak-uho/issue/archive

e-ISSN: 2088-4656

\begin{tabular}{|c|c|c|c|c|}
\hline Juli & 41.900 .000 & 3.050 .000 & - & 44.950 .000 \\
\hline Agustus & 41.900 .000 & 3.100 .000 & 5.000 .000 & 50.000 .000 \\
\hline September & 41.900 .000 & 3.050 .000 & - & 44.950 .000 \\
\hline Oktober & 41.900 .000 & 3.100 .000 & 100.000 & 45.100 .000 \\
\hline November & 41.900 .000 & 2.950 .000 & - & 44.850 .000 \\
\hline Desember & 41.900 .000 & 3.000 .000 & 3.250 .000 & 48.150 .000 \\
\hline Jumlah & 41.900 .000 & 37.500 .000 & 15.890 .000 & 95.290 .000 \\
\hline \multicolumn{5}{|c|}{ DATA SIMPANAN ANGGOTA 2019} \\
\hline \multirow[b]{2}{*}{ Bulan } & \multicolumn{3}{|c|}{ Simpanan } & \multirow[b]{2}{*}{ Jumlah (Rp) } \\
\hline & Pokok (Rp) & $\begin{array}{l}\text { Wajib } \\
\text { (Rp) }\end{array}$ & $\begin{array}{r}\text { Sukarela } \\
(\mathrm{Rp})\end{array}$ & \\
\hline Januari & 48.800 .000 & 2.900 .000 & 7.120 .000 & 58.820 .000 \\
\hline Februari & 48.800 .000 & 2.850 .000 & 790.000 & 52.440 .000 \\
\hline Maret & 48.800 .000 & 2.750 .000 & 3.449 .000 & 54.999 .000 \\
\hline April & 48.800 .000 & 2.800 .000 & 6.646 .000 & 58.246 .000 \\
\hline Mei & 48.800 .000 & 2.800 .000 & 250.000 & 51.850 .000 \\
\hline Juni & 48.800 .000 & 2.750 .000 & 1.000 .000 & 52.550 .000 \\
\hline Juli & 48.800 .000 & 2.800 .000 & 450.000 & 52.050 .000 \\
\hline Agustus & 48.800 .000 & 2.900 .000 & 80.000 & 51.780 .000 \\
\hline September & 48.800 .000 & 2.750 .000 & 2.600 .000 & 54.150 .000 \\
\hline Oktober & 48.800 .000 & 2.850 .000 & 400.000 & 52.050 .000 \\
\hline November & 48.800 .000 & 2.800 .000 & 2.580 .000 & 54.180 .000 \\
\hline Desember & 48.800 .000 & 2.750 .000 & 2.500 .000 & 54.050 .000 \\
\hline Jumlah & 48.800 .000 & 33.700 .000 & 27.865 .000 & 110.365 .000 \\
\hline
\end{tabular}

Sumbe : Data sekunder Catatan Keuangan KSU Bina Sejahtera tahun 2017-2019

Data Variabel Pinjaman Anggota KSU Bina Sejahtera

\begin{tabular}{|l|r|r|r|}
\hline \multirow{2}{*}{ Bulan } & \multicolumn{3}{|c|}{ Pinjaman Anggota (Piutang Anggota) } \\
\cline { 2 - 4 } & $\begin{array}{r}\text { Tahun } \\
2017\end{array}$ & Tahun 2018 & Tahun 2019 \\
\hline Januari & 29.000 .000 & 33.000 .000 & 40.000 .000 \\
\hline Februari & 22.000 .000 & 18.000 .000 & 37.000 .000 \\
\hline Maret & 21.000 .000 & 47.000 .000 & 3.000 .000 \\
\hline April & 10.000 .000 & 28.500 .000 & 45.000 .000 \\
\hline Mei & 34.000 .000 & 47.500 .000 & 75.000 .000 \\
\hline Juni & 22.000 .000 & 49.000 .000 & 43.000 .000 \\
\hline Juli & 20.000 .000 & 18.000 .000 & 58.000 .000 \\
\hline Agustus & 28.000 .000 & 43.000 .000 & 63.000 .000 \\
\hline September & 40.000 .000 & 42.000 .000 & 43.000 .000 \\
\hline Oktober & 15.000 .000 & 38.000 .000 & 52.000 .000 \\
\hline November & 47.500 .000 & 33.000 .000 & 33.000 .000 \\
\hline
\end{tabular}


Jurnal Akuntansi dan Keuangan (JAK)

Volume 6, No. 2 Oktober Tahun 2021

Page: 80 - 96

http://ojs.uho.ac.id/index.php/jak-uho/issue/archive

e-ISSN: 2088-4656

\begin{tabular}{|l|r|r|r|}
\cline { 2 - 4 } Desember & 41.000 .000 & 45.000 .000 & 68.000 .000 \\
\hline Jumlah & 329.500 .000 & 442.000 .000 & 560.000 .000 \\
\hline
\end{tabular}

Sumber : Data sekunder Catatan Keuangan KSU Bina Sejahtera tahun 2017-2019

Data Variabel Sisa Hasil Usaha (SHU) KSU Bina Sejahtera

\begin{tabular}{|l|r|r|r|}
\hline \multicolumn{4}{|c|}{ DATA SHU KOPERASI 2017 } \\
\hline Bulan & $\begin{array}{c}\text { Penghasilan Usaha } \\
\text { Simpan Pinjam } \\
(\mathrm{Rp})\end{array}$ & Beban (Rp) & Jumlah (Rp) \\
\hline Januari & 1.870 .000 & 1.018 .900 & 851.100 \\
\hline Februari & 2.030 .000 & 1.214 .500 & 815.500 \\
\hline Maret & 2.000 .000 & 1.315 .000 & 685.000 \\
\hline April & 2.150 .000 & 1.020 .000 & 1.130 .000 \\
\hline Mei & 1.970 .000 & 1.020 .500 & 949.500 \\
\hline Juni & 2.310 .000 & 1.196 .000 & 1.114 .000 \\
\hline Juli & 2.310 .000 & 1.021 .000 & 1.289 .000 \\
\hline Agustus & 2.270 .000 & 1.020 .500 & 1.249 .500 \\
\hline September & 2.270 .000 & 1.105 .000 & 1.165 .000 \\
\hline Oktober & 2.490 .000 & 1.019 .500 & 1.470 .500 \\
\hline November & 2.410 .000 & 1.020 .000 & 1.390 .000 \\
\hline Desember & 2.595 .000 & 1.020 .000 & 1.575 .000 \\
\hline Jumlah & 26.675 .000 & 12.990 .900 & 13.684 .100 \\
\hline
\end{tabular}

DATA SHU KOPERASI 2018

\begin{tabular}{|l|r|r|r|}
\hline \multicolumn{1}{|c|}{ Bulan } & $\begin{array}{c}\text { Penghasilan Usaha } \\
\text { Simpan Pinjam } \\
\text { (Rp) }\end{array}$ & Beban (Rp) & Jumlah (Rp) \\
\hline Januari & 2.785 .000 & 1.085 .000 & 1.700 .000 \\
\hline Februari & 2.905 .000 & 1.271 .000 & 1.634 .000 \\
\hline Maret & 2.985 .000 & 1.221 .000 & 1.764 .000 \\
\hline April & 3.115 .000 & 1.086 .000 & 2.029 .000 \\
\hline Mei & 3.180 .000 & 1.089 .800 & 2.090 .200 \\
\hline Juni & 3.455 .000 & 1.090 .200 & 2.364 .800 \\
\hline Juli & 3.665 .000 & 1.071 .500 & 2.593 .500 \\
\hline Agustus & 3.445 .000 & 1.073 .300 & 2.371 .700 \\
\hline September & 3.725 .000 & 1.273 .925 & 2.451 .075 \\
\hline Oktober & 3.670 .000 & 1.334 .425 & 2.335 .575 \\
\hline November & 3.640 .000 & 1.070 .950 & 2.569 .050 \\
\hline Desember & 3.640 .000 & 1.574 .400 & 2.065 .600 \\
\hline Jumlah & 40.210 .000 & 14.241 .500 & 25.968 .500 \\
\hline
\end{tabular}


Jurnal Akuntansi dan Keuangan (JAK)

Volume 6, No. 2 Oktober Tahun 2021

Page: 80 - 96

http://ojs.uho.ac.id/index.php/jak-uho/issue/archive

e-ISSN: 2088-4656

\begin{tabular}{|l|r|r|r|}
\hline \multicolumn{4}{|c|}{ DATA SHU KOPERASI 2019 } \\
\hline Bulan & $\begin{array}{c}\text { Penghasilan Usaha } \\
\text { Simpan Pinjam } \\
\text { (Rp) }\end{array}$ & Beban (Rp) & Jumlah (Rp) \\
\hline Januari & 3.910 .000 & 1.164 .075 & 2.745 .925 \\
\hline Februari & 3.840 .000 & 1.376 .100 & 2.463 .900 \\
\hline Maret & 3.925 .000 & 1.217 .750 & 2.707 .250 \\
\hline April & 3.480 .000 & 1.159 .350 & 2.320 .650 \\
\hline Mei & 3.440 .000 & 1.166 .150 & 2.273 .850 \\
\hline Juni & 4.010 .000 & 1.162 .100 & 2.847 .900 \\
\hline Juli & 4.010 .000 & 1.168 .310 & 2.841 .690 \\
\hline Agustus & 4.170 .000 & 1.170 .350 & 2.999 .650 \\
\hline September & 4.420 .000 & 1.168 .300 & 3.251 .700 \\
\hline Oktober & 4.520 .000 & 1.166 .250 & 3.353 .750 \\
\hline November & 4.590 .000 & 1.666 .250 & 2.923 .750 \\
\hline Desember & 4.520 .000 & 1.226 .350 & 3.293 .650 \\
\hline Jumlah & 48.835 .000 & 14.811 .335 & 34.023 .665 \\
\hline
\end{tabular}

Sumber : Data sekunder Catatan Keuangan KSU Bina Sejahtera tahun 2017-2019

Tabel di atas memperlihatkan bahwa jumlah simpanan anggota dan pinjaman anggota, dan Sisa Hasil Usaha pada KSU Bina Sejahtera di tahun 2017 s.d 2019 ratarata mengalami peningkatan. Meskipun tingkat peningkatan simpanan anggotanya setiap bulannya bermain. peningkatan SHU diiringi dengan peningkatan jumlah simpanan anggota dan pinjaman anggota.

\section{Hasil Statistik Deskriptif}

\section{Hasil Statistik Deskpritif \\ Descriptive Statistics}

\begin{tabular}{l|r|r|r|r|r|r} 
& N & Minimum & Maximum & Sum & Mean & $\begin{array}{c}\text { Std. } \\
\text { Deviation }\end{array}$ \\
\hline Simpanan & 36 & 43090000 & 63590000 & 1744670000 & 48463055,56 & 5402542,872 \\
\hline Piutang & 36 & 3000000 & 75000000 & 1331500000 & 36986111,11 & 15917414,59 \\
& & & & & & 2 \\
\hline SHU & 36 & 685000 & 3353750 & 73676265 & 2046562,92 & 774182,835 \\
\hline $\begin{array}{l}\text { Valid N } \\
\quad \text { (listwise) }\end{array}$ & 36 & & & & & \\
\hline \begin{tabular}{l} 
Sumber : Data diolah Penulis (2021) \\
\hline
\end{tabular}
\end{tabular}

Tabel di atas menunjukkan nilai statistik deskriptif dari variabel dalam penelitian ini. Adapun penjelasannya sebagai berikut : 
Jurnal Akuntansi dan Keuangan (JAK)

Volume 6, No. 2 Oktober Tahun 2021

Page: 80 - 96

http://ojs.uho.ac.id/index.php/jak-uho/issue/archive

e-ISSN: 2088-4656

1. Untuk variabel simpanan anggota memiliki banyak data sebanyak (n) yaitu 36. Dari data tersebut diketahui bahwa nilai minimumnya adalah sebesar 43090000 dan nilai maximumnya sebesar 63590000 dengan total keseluruhan (sum) sebesar 1744670000. Rata-rata (mean) data tersebut adalah 48463055,56, dan standar deviasi 5402542,872.

2. Untuk variabel pinjaman anggota memiliki banyak data sebanyak (n) yaitu 36. Dari data tersebut diketahui bahwa nilai minimumnya adalah sebesar 3000000 dan nilai maximumnya sebesar 75000000 dengan total keseluruhan (sum) sebesar 1331500000. Rata-rata (mean) data tersebut adalah 36986111,11, dan standar deviasi 15917414,592.

3. Hasil analisis pada variabel Sisa Hasil Usaha (SHU) memiliki banyak data sebanyak (n) yaitu 36. Dari data tersebut diketahui bahwa nilai minimumnya adalah sebesar 685000 dan nilai maximumnya sebesar 3353750 dengan total keseluruhan (sum) sebesar 73676265. Dan Rata-rata (mean) sebesar 2046562,92,serta standar deviasi sebesar 774182,835.

\section{Hasil Uji Asumsi Klasik}

1. Uji Normalitas

\section{Hystogram Standardized Regression Residual Variabel SHU}

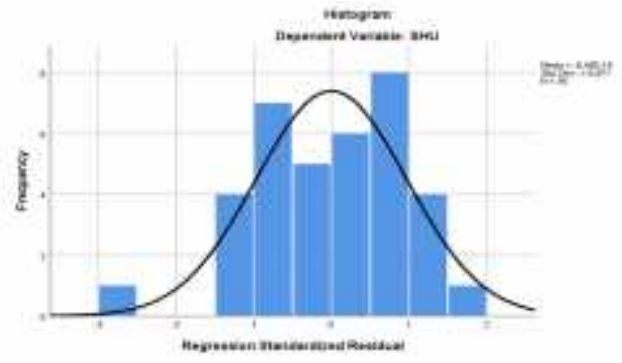

Sumber : Data diolah Penulis (2021)

Garis histogram menampakan bahwa hystogram standardized regression residual membentuk kurva seperti lonceng maka nilai residual tersebut dinyatakan normal. Dengan demikian model regresi dari persamaan regresi SHU telah memenuhi asumsi normalitas.

Uji normalitas juga dilakukan dengan menggunakan normal probability plot:

\section{Grafik Normal Probability Plot Variabel SHU}

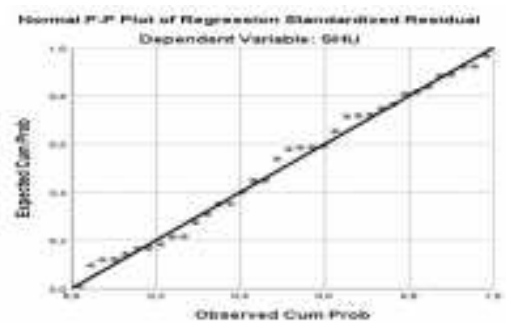

Sumber : Data diolah Penulis (2021) 
Jurnal Akuntansi dan Keuangan (JAK)

Volume 6, No. 2 Oktober Tahun 2021

Page: 80 - 96

http://ojs.uho.ac.id/index.php/jak-uho/issue/archive

e-ISSN: 2088-4656

Grafik normal probability plot pada grafik dapat dilihat bahwa titik-titik menyebar disekitar garis diagonal, serta penyebarannya mengikuti arah garis diagonal. Sehingga model regresi dari persamaan regresi SHU dapat diartikan layak dipakai dan memenuhi standar normalitas.

2. Uji Multikolonieritas

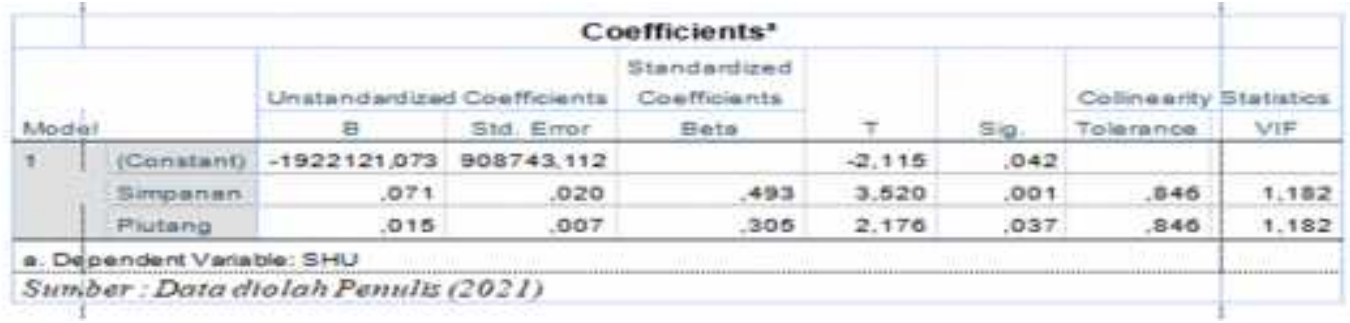

Dari tabel di atas menunjukkan bahwa model regresi dengan variabel dependen atau terikat SHU, dan untuk semua variabel bebas memiliki nilai tolerance $>0,10$ dan nilai VIF < 10. Dengan demikian, pada model regresi SHU menunjukkan bahwa tidak adanya korelasi antar variabel bebas sehingga dapat disimpulkan tidak terjadi multikolonieritas.

3. Uji Heteroskedastisitas

\section{Scatterplot Variabel Dependen SHU}

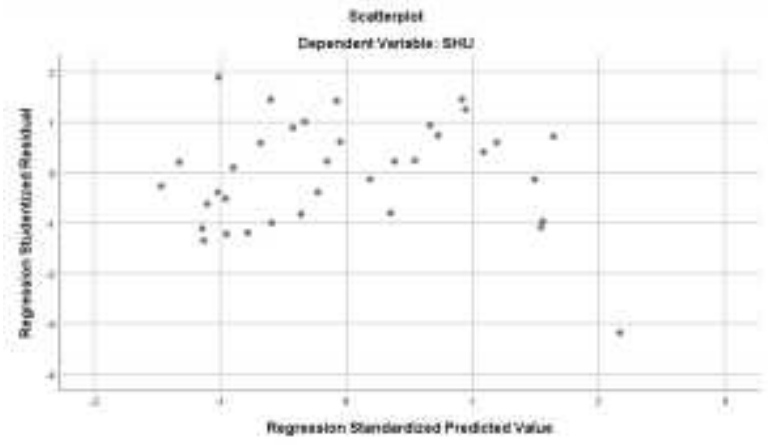

Sumber : Data diolah Penulis (2021)

Terlihat bahwa plot menyebar secara acak di atas maupun di bawah angka nol pada sumbu regression studentized residual. Sehingga, berdasarkan uji heterokedastisitas menggunakan metode analisis grafik menunjukkan bahwa pada model regresi yang terbentuk tidak terjadi heteroskedastisitas.

4. Uji Autokorelasi

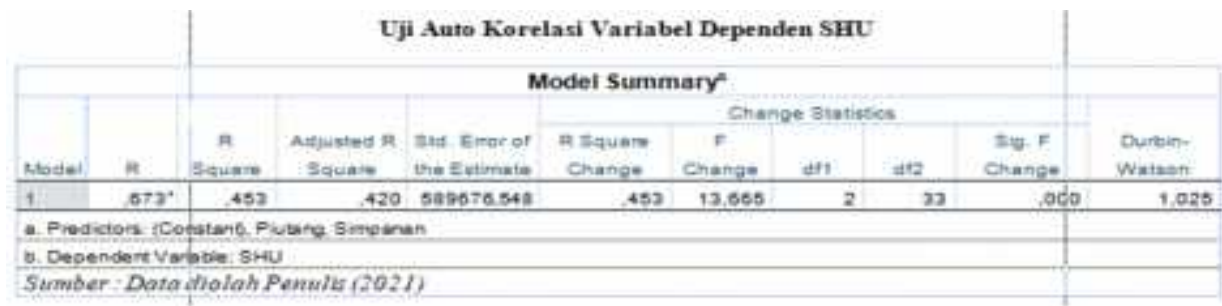

Sumber : Data diolah Penulis (2021) 
Jurnal Akuntansi dan Keuangan (JAK)

Volume 6, No. 2 Oktober Tahun 2021

Page: 80 - 96

http://ojs.uho.ac.id/index.php/jak-uho/issue/archive

e-ISSN: 2088-4656

Menunujukan bahwa nilai Durbin Watson menunjukkan angka 1,025. Berdasarkan asumsi diatas, maka angka Durbin Watson terletak di antara -2 dan $+2(-2<$ DW $<$ +2 ) sehingga dapat dikatakan bahwa persamaan regresi SHU tidak terjadi autokorelasi.

\section{Hasil Analisis Regresi Linear Berganda}

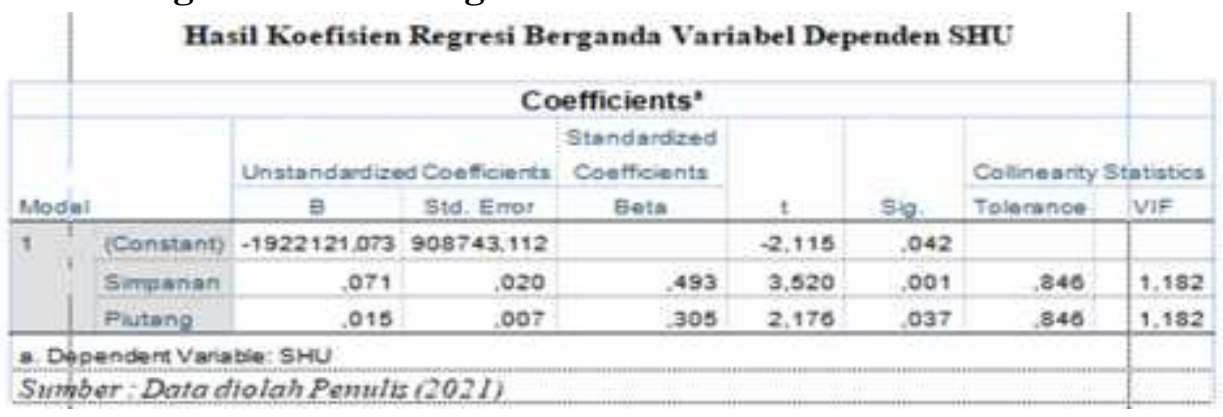

Sumber : Data diolah Penulis (2021)

Persamaan Sisa Hasil Usaha (SHU) sebagai berikut :

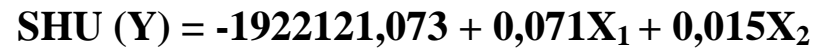

Nilai konstanta dengan koefisien regresi pada tabel di atas dapat dijelaskan sebagai berikut :

1. Nilai konstanta bernilai negatif yaitu sebesar $-1922121,073$. Hal ini berarti bahwa jika variabel simpanan anggota dan pinjaman anggota memiliki nilai konstan atau sama dengan nol, maka Sisa Hasil Usaha (SHU) koperasi akan konstan sebesar 1922121,073 .

2. Nilai $\beta_{1}$ sebesar 0,071 yang berarti bahwa jika terjadi kenaikan pada variabel simpanan anggota sebanyak satu satuan, maka akan menyebabkan terjadinya kenaikan SHU sebesar 0,071 disaat variabel pinjaman anggota tidak mengalami perubahan.

3. Nilai $\beta_{2}$ sebesar 0,015 yang berarti bahwa jika terjadi kenaikan pada variabel pinjaman anggota sebanyak satu satuan, maka akan menyebabkan terjadinya kenaikan SHU sebesar 0,015 saat variabel simpanan anggota tidak mengalami perubahan.

\section{Uji Hipotesis}

1. Uji Signifikan Parsial (Uji-t)

hasil dari regresi berganda pada persamaan SHU (Y) dapat dianalisis sebagai berikut :

a. Pengaruh Simpanan Anggota terhadap Sisa Hasil Usaha (SHU), diperoleh hasil bahwa nilai t-hitung untuk simpanan anggota yaitu sebesar 3,520 > t-tabel $(1,69236)$ dan memiliki nilai signifikan sebesar $0,001<\alpha=0,05$. Hasil ini menggambarkan bahwa variabel simpanan anggota secara parsial berpengaruh signifikan dan positif terhadap SHU atau $\mathrm{H}_{1}$ diterima dan $\mathrm{H}_{0}$ di tolak. 
Jurnal Akuntansi dan Keuangan (JAK)

Volume 6, No. 2 Oktober Tahun 2021

Page: 80 - 96

http://ojs.uho.ac.id/index.php/jak-uho/issue/archive

e-ISSN: 2088-4656

b. Pengaruh Pinjaman Anggota terhadap Sisa Hasil Usaha (SHU), diperoleh hasil bahwa nilai t-hitung untuk pinjaman anggota yaitu sebesar 2,176 > t-tabel $(1,69236)$ dan memiliki nilai signifikan sebesar $0,037<\alpha=0,05$. Hasil ini menggambarkan bahwa variabel pinjaman anggota secara parsial berpengaruh signifikan dan positif terhadap $\mathrm{SHU}$ atau $\mathrm{H}_{1}$ diterima dan $\mathrm{H}_{0}$ di tolak.

2. Uji Signifikan Simultan (Uji-F)

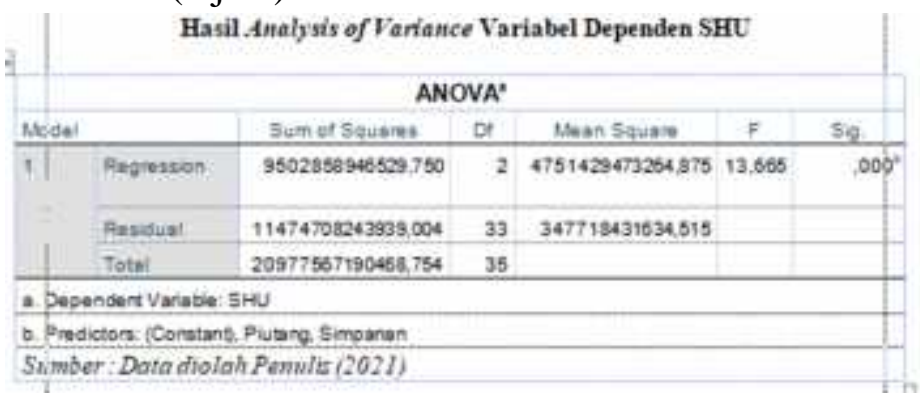

Sumber : Data diolah Penulis (2021)

Dapat diperoleh bahwa nilai F-hitung sebesar 13,665 dan nilai signifikan sebesar 0,000 , yaitu nilai $\mathrm{F}_{\text {-hitung }}(13,665)>\mathrm{F}_{\text {-tabel }}(3,2800)$ dan memiliki nilai signifikan $(0,000)$ $<\alpha=0,05$. Hasil ini menunjukkan bahwa variabel simpanan anggota dan pinjaman anggota secara bersama-sama (simultan) berpengaruh signifikan dan positif terhadap SHU atau $\mathrm{H}_{0}$ ditolak dan $\mathrm{H}_{1}$ diterima.

3. Koefisien Determinasi $\left(\mathrm{R}^{2}\right)$

Hasil Perhitungan $R$ Square $\left(R^{2}\right)$ Variabel Dependen SHU $(\mathrm{Y})$

\begin{tabular}{|c|c|c|c|c|c|}
\hline \multicolumn{6}{|c|}{ Model Summary } \\
\hline Model & R & R Square & $\begin{array}{l}\text { Adjusted } R \\
\text { Square }\end{array}$ & $\begin{array}{c}\text { Std Emotef the } \\
\text { Estimate }\end{array}$ & Durbin Watson \\
\hline 1 & $.573^{*}$ & 453 & 420 & 589676,548 : & 1,025 \\
\hline \multicolumn{6}{|c|}{ a. Predictors (Constsont. Pivare Simescan } \\
\hline \multicolumn{6}{|c|}{ b. Dependere Varioble: SHU } \\
\hline \multicolumn{6}{|c|}{ Sumber Data diolah Penults 2021$)$} \\
\hline
\end{tabular}

Sumber : Data diolah Penulis (2021)

Diketahui bahwa besarnya nilai $R$-Square $\left(\mathrm{R}^{2}\right)=0,453$. Hasil ini menunjukkan bahwa besarnya pengaruh langsung variabel simpanan anggota dan pinjaman anggota terhadap Sisa Hasil Usaha (SHU) adalah sebesar 45,30\%. Hal ini berarti bahwa ada variabel lain atau variabel epselon ( ) sebesar 54,70\% yang mempengaruhi variabel SHU (Y), namun tidak diukur dalam penelitian ini, misalnya pendapatan usaha lain yang ada pada koperasi antara lain pendapatan jasa dekorasi pengantin, penjualan barang kepada anggota koperasi, dan lain sebagainya.

\section{Pembahasan}

\section{Pengaruh Simpanan Anggota terhadap Sisa Hasil Usaha (SHU) Koperasi}

Variabel simpanan anggota berpengaruh signifikan dan positif terhadap Sisa Hasil Usaha (SHU) koperasi pada Koperasi Serba Usaha (KSU) Bina Sejahtera. Pengaruh simpanan anggota yang signifikan dan positif terhadap SHU koperasi tersebut 
Jurnal Akuntansi dan Keuangan (JAK)

Volume 6, No. 2 Oktober Tahun 2021

Page: 80 - 96

http://ojs.uho.ac.id/index.php/jak-uho/issue/archive

e-ISSN: 2088-4656

didukung oleh adanya peningkatan simpanan anggota yang disetorkan oleh anggota koperasi pada KSU Bina Sejahtera.

Hasil penelitian ini sesuai dengan penelitian yang dilakukan oleh Saputra (2017) menyatakan bahwa adanya pengaruh yang signifikan secara parsial atas Sisa Hasil Operasi (SHU).

\section{Pengaruh Pinjaman Anggota terhadap Sisa Hasil Usaha (SHU) Koperasi}

Pinjaman anggota yaitu piutang anggota berpengaruh secara signifikan dan positif terhadap Sisa Hasil Usaha (SHU) koperasi pada Koperasi Serba Usaha (KSU) Bina Sejahtera di Desa Lemoambo. Hasil tersebut ditunjukan pada tabel perhitungan persamaan regresi linear berganda yang telah dilakukan dengan berdasarkan data yang menempilkan bahwa adanya peningkatan pinjaman anggota yang diikuti oleh peningkatan SHU koperasi pada KSU Bina Sejahtera.

Hasil Penelitian ini sejalan dengan penelitian yang dilakukan oleh Iqbal dan Widiya (2018) menyimpulkan bahwa pinjaman terhadap Sisa Hasil Usaha mempunyai hubungan yang sangat kuat karena hasilnya positif, maka dapat disimpulkan bahwa setiap kenaikan pinjaman anggota akan diikuti oleh kenaikan Sisa Hasil Usaha.

\section{Pengaruh Simpanan Anggota dan Pinjaman Anggota terhadap Sisa Hasil Usaha (SHU) Koperasi}

Variabel simpanan anggota dan pinjaman anggota (piutang anggota) berpengaruh signifikan dan positif secara bersama-sama terhadap Sisa Hasil Usaha Koperasi pada Koperasi Serba Usaha (KSU) Bina Sejahtera. Hasil ini dipengaruhi oleh meningkatnya simpanan anggota dan pinjaman anggota yang diikuti dengan meningkatnya SHU.

Hasil Penelitian ini sejalan dengan penelitian yang dilakukan oleh Haqiqi, dkk (2020) yang menyebutkan bahwa simpanan anggota dan pinjaman angota secara simultan berpengaruh signifikan terhadap Sisa Hasil Usaha (SHU).

\section{KESIMPULAN, IMPLIKASI, KETERBATASAN, DAN REKOMENDASI Kesimpulan}

Berdasarkan hasil penelitian dan pembahasan di atas, maka peneliti dapat menarik beberapa kesimpulan sebagai berikut :

1. Simpanan anggota sacara parsial berpengaruh signifikan dan positif kepada Sisa Hasil Usaha (SHU) koperasi. Artinya, jumlah besaran simpanan anggota mempengaruhi tingkat jumlah besaran SHU, dengan jumlah simpanan anggota yang naik akan membuat modal koperasi meningkat dalam melakukan usahanya sehingga akan meningkat SHU koperasi atas penghasilan usaha yang dilakukan oleh Koperasi Serba Usaha Bina Sejahtera.

2. Pinjaman anggota (piutang anggota) berpengaruh signifikan dan positif secara parsial terhadap Sisa Hasil Usaha (SHU). Artinya, peningkatan jumlah piutang anggota akan memberikan dampak atas meningkatnya jumlah SHU koperasi pada Koperasi Serba Usaha Bina Sejahtera. Dengan adanya peningkatan jumlah piutang 
Jurnal Akuntansi dan Keuangan (JAK)

Volume 6, No. 2 Oktober Tahun 2021

Page: 80 - 96

http://ojs.uho.ac.id/index.php/jak-uho/issue/archive

e-ISSN: 2088-4656

anggota, akan meningkatkan penghasilan jasa atas piutang tersebut. Penghasilan jasa piutang yang meningkat memberikan efek yang baik kepada SHU koperasi.

3. Simpanan anggota dan pinjaman anggota (piutang anggota) secara simultan atau bersama-sama memberikan pengaruh yang signifikan dan positif terhadap Sisa Hasil Usaha. Artinya, setiap kenaikan dari simpanan anggota serta piutang anggota maka akan diikuti oleh kenaikan SHU koperasi pada Koperasi Serba Usaha Bina Sejahtera. Namun apabila simpanan anggota dan piutang anggota tidak mengalami perubahan, maka SHU akan mengalami penurunan.

\section{Implikasi}

Adapun implikasi dalam penelitian ini adalah yaitu bagi dewan pengurus Koperasi Serba Usaha Bina Sejahtera dalam meningkatkan Sisa Hasil Usaha agar meningkatkan tingkat kedisiplinan anggota dalam melakukan penyetoran simpanan anggota maupun pelunasan piutang anggotanya.

\section{Keterbatasan}

Penelitian ini hanya hanya menggunakan 3 variabel, dimana 2 variabel independent yaitu Simpanan Anggota dan Pinjaman Anggota dan 1 variabel dependent yaitu Sisa Hasil Usaha pada Koperasi Serba Usaha Bina Sejahtera.

\section{Rekomendasi}

Berdasarkan hasil analisis pembahasan serta beberapa kesimpulan di atas, maka peniliti dapat mengemukakan saran-saran sebagai berikut :

1. Bagi Koperasi Serba Usaha (KSU) Bina Sejahtera

a. Diharapkan kepada pihak pengurus KSU Bina Sejatera perlu lebih mengoptimalkan simpanan dan piutang anggota dengan langkah menetapkan target besaran simpanan dan piutang anggota setiap tahunnya.

b. Koperasi Serba Usaha (KSU) Bina Sejahtera diharapkan terus mengoptimalkan peningkatan jumlah simpanan anggota dengan langkah peningkatan jumlah anggota, serta melakukan pengawasan serta kebijakan penegasan kepada anggotanya untuk menyetorkan simpanannya secara disiplin.

c. Koperasi Serba Usaha (KSU) Bina Sejahtera diharapkan meningkatan piutang anggota serta memperbaiki kebijakan atau melakukan penagihan secara langsung dan tepat waktu untuk mengatasi pelunasan piutang anggota yang bermasalah atau menunggak.

2. Bagi peneliti selanjutnya, diharapkan peneliti selanjutnya melakukan penelitian dengan menambah Variabel lain atau faktor-faktor lain yang mempengaruhi peningkatan Sisa Hasil Usaha (SHU) selain simpanan dan pinjaman anggota, seperti pendapatan lain seperti pendapatan jasa dekorasi pengantin, penjualan barang kepada anggotanya, dan lain sebagainya. 
Jurnal Akuntansi dan Keuangan (JAK)

Volume 6, No. 2 Oktober Tahun 2021

Page: 80 - 96

http://ojs.uho.ac.id/index.php/jak-uho/issue/archive

e-ISSN: 2088-4656

\section{DAFTAR PUSTAKA}

Ghozali, Imam, 2016. Aplikasi Analisis Multivariate Dengan Program IBM SPSS23, Edisi Delapan, Semarang : Badan Penerbit Universitas Diponegoro.

Haikalus Shomadani, Muhammad, \& Hasyim, Nur 2018. Ekonomi Koperasi, Pasuruan : Fakultas Agama Islam Universitas Yudharta Pasuruan.

Peraturan Menteri Koperasi dan Usaha Kecil dan Menengah Republik Indonesia Nomor 13/per/m.kukm/ix/2015 tentang Pedoman Akuntansi Usaha Simpan Pinjam Oleh Koperasi.

Peraturan Menteri Koperasi dan Usaha Kecil dan Menengah Republik Indonesia Nomor 15/Per/M.KUKM/IX/2015 Tentang Usaha Simpan Pinjam Oleh Koperasi.

Rudianto. 2010. Akuntansi Koperasi. Edisi Kedua. Jakarta : Erlangga

Satar, Muhammad, \& Wulan Sari, Sri. 2019. Pengaruh Simpanan dan Pinjaman Anggota Terhadap Sisa Hasil Usaha (SHU). Akurat Jurnal Ilmiah Akuntansi. Volume 10, Nomor 2, hlm 80-92, Mei-Agustus 2019, P-ISSN 2086-4159.

Sugiyono. 2017. Metode Penelitian Bisnis pendekatan Kuantitatif, Kualitatif, kombinasi dan $R \& D$, Bandung : Alfabeta.

Sunyoto, Danang. 2016. Metodologi Penelitian Akuntansi. Bandung : PT Refika Aditama.

Undang-Undang Republik Indonesia Nomor 25 Tahun 1992 tentang Perkoperasian. 